\title{
Кыргызстандын Чүй өрөөнүндө кулпунай (Fragaria ananassa Duch) өстүрүлгөн талааларда өсүмдүк паразиттик нематоддорду аныктоо
}

\author{
Таир Эсенали уулу ${ }^{1 a^{*}}$ Эламан Канатбек уулу ${ }^{2 b}$ Шенол Йылдыз $3^{1,3 c}$
}

\begin{abstract}
${ }^{1}$ Кыргыз-Түрк Манас Университети, Айыл-чарба факультети, Өсүмдүктөрдү коргоо бөлүмү, Бишкек, Кыргызстан ${ }^{2}$ Кыргыз-Түрк Манас Университети, Табигый илимдер институту, Өсүмдүктөрдү коргоо билим багыты, Бишкек, Кыргызстан ${ }^{3}$ Абант Иззет Байсал Университети, Айыл-чарба факультети, Табият экологиясы жана башкаруу бөлүмү, Болу, Түркия
\end{abstract}

${ }^{a}$ https://orcid.org/0000-0002-7550-9931, chttps://orcid.org/0000-0001-7072-0087

*Корреспондент автор: tair.esenaliuulu@manas.edu.kg

\section{АННОТАЦИЯ}

Кулпунай Fragaria ananassa Duch. дүйнө жүзүндө кеңири аянттарда өстүрүлгөн, көп жылдык чөп өсүмдүгү. Ал субтропикалык жылуу, салкын климатта эң жакшы өсүп, анын жемиштери өзгөчө өңү, жыты жана даамы менен адамзат үчүн өтө баалуу азык болуп саналат. Кулпунай толук бышкан абалында таза түрүнде, андан сырткары таттууларды жана ичимдиктерди жасоодо колдонулат. Кулпунай өстүрүүчүлүк Кыргызстанда маанилүү жана артыкчылыктуу багыт болуп саналат. Кыргызстанда кулпунай негизинен талаа шарттарында өстүрүлөт, ошондуктан жай мезгилинде бышат жана сатыкка чыгат. Кулпунай башка өсүмдүктөр сыяктуу эле өстүрүү учурунда түрдүү илдеттер жана зыянкечтер тарабынан жабыркайт. Илдеттер жана зыянкечтерден сырткары, нематоддор өсүмдүктүн тамыр айланасында жашап, өсүмдүктүн азыктануусун начарлатып, түшүмдү азайтат. Бул илимий иштин алкагында Кыргызстандын эң көп кулпунай өстүрүлгөн аймагы болгон Чүй облусундагы кулпунай талааларындагы өсүмдүк паразиттик нематоддору изилденди. Жалпы жыйырма беш топурак үлгүсү жана жети өсүмдүк үлгүсү чогултулуп, изилдөөнүн жыйынтыгында 10 урууга кирген өсүмдүк паразиттик нематоддору аныкталды. Алар, Aphelenchoides, Aphelenchus, Criconema, Ditylenchus, Gracilacus, Helicotylenchus, Paratylenchus, Pratylenchus, Tylenchorhynus жана Tylenchus уруулары болуп, алардын ичинен Tylenchus жана Helicotylenchus уруулары 88 \% жана 72 \% катышы менен эң көп кездешкен уруулар болушту. Изилдөөдө Tylenchus жана Helicotylenchus урууларынан башка уруулардын кездешүүсү 50 \% дан төмөн болушуп, тыгыздыгы жагынан да төмөн көрсөткүчтөргө ээ экендиги байкалды. Кулпунайдын коркунучтуу нематодасы, Aphelenchoides fragariae, талааларда өтө аз жыштыкта экендиги белгилүү болду. Үлгүлөрдөн Meloidogyne уруусуна кирген түрлөр табылган жок. Алынган жыйынтыктарга жараша, Кыргызстандын Чүй өрөөнүндөгү кулпунай өстүрүлгөн талааларында кээ бир өсүмдүк паразиттик нематоддору бар экендиги аныкталып, бирок, бул нематоддордун түрлөрү, кездешүү пайызы жана тыгыздыгы жагынан азырынча көйгөй эмес экендиги, ошону менен бирге, мындан ары кулпунай талааларындагы нематоддорду изилдөө иштери улантылуусу керектиги белгиленди.

\section{A Survey for Plant-Parasitic Nematodes Associated with Strawberry (Fragaria ananassa Duch) Crop in Chui Province, Kyrgyzstan}

\section{A B S T R A C T}

Strawberry Fragaria ananassa Duch. is a perennial herbaceous plant grown in large areas around the world. It grows best in subtropical warm, cool climates, and its fruits are a very valuable food for human with its unique color, aroma and taste. Strawberries are used in pure form when fully ripe, as well as in the manufacture of sweets and beverages. Strawberry growing is an important and priority area in Kyrgyzstan and is grown mainly in the field, so they ripen in summer and go on sale. Strawberries, like other plants, are susceptible to various diseases and pests during cultivation. In addition to diseases and pests, nematodes live around the plant's roots, impairing plant nutrition and reducing yields. A survey was conducted in Chuy province, which is major strawberry growing region in Kyrgyzstan to study the occurrence of plant-parasitic nematodes associated with strawberry. A total 25 soil and 7 foliage samples containing mixed populations of 10 genera belonging to order Tylenchida were analyzed. The identified genera were: Aphelenchoides, Aphelenchus, Criconema, Ditylenchus, Gracilacus, Helicotylenchus, Paratylenchus, Pratylenchus, Tylenchorhynus and Tylenchus. Frequency and density of each genera were variable from field to field. Tylenchus and Helicotylenchus genera were most frequent with $88 \%$ and $72 \%$, respectively. A dangerous nematode of strawberry, Aphelenchoides fragariae, has been found to occur in very low frequencies in fields. No species belonging to the genus Meloidogyne were found in the specimens. However, many of the observed species are important parasites of strawberry, but it is not serious problem for region according to species status, prevalence and frequency.
МАКАЛА

МА АЛ Ы М А Т Ы

Илимий макала

ЖиберүҮ: 10.05.2021

Кабыл кылуу: 22.11.2021

Ачкыч сөздөр: Кулпунай, Fragaria ananassa, нематоддор, Кыргызстан

To Cite: Эсенали уулу Т, Канатбек уулу Э, Йылдыз Ш 2021. Кыргызстандын Чүй өрөөнүндө кулпунай (Fragaria ananassa Duch) өстүрүлгөн талааларда өсүмдүк паразиттик нематоддорду аныктоо. MJAVL Sciences. 11 (2) 179-185 


\section{КИРИШУУ}

Кулпунай Fragaria ananassa Duch. дүйнө жүзүндө кеңири аянттарда өстүрүлгөн, көп жылдык чөп өсүмдүгү. Ал субтропикалык жылуу, салкын климатта эң жакшы өсүп, анын жемиштери өзгөчө өңү, жыты жана даамы менен адамзат үчүн өтө баалуу азык болуп саналат. Кулпунай толук бышкан абалында таза түрүндө, андан сырткары татууларды жана ичимдиктерди жасоодо колдонулат (Chandler et al., 2012). Кулпунайдын тамыры сабактуу, сабагы төшөлүп, бутактанган, жалбырактары үч бурчтук формада, кочкул-жашыл түстө болот. Гүл сабактары жалбырактарынын деңгээлинде же андан төмөн жайгашкан, гүлү ак түстө, гүл чыгаруучу жерлери тамыр моюнчасынан розетка сыяктуу чыгышат. Мөмөсү конустук, шар формасында, каралжын кочкул, кызыл түстүҮ. Уруктары мөмөгө анча-мынча басылган. Жемиштери орто көлөмдүҮ, 8-10 г. даамы таттуу, ширелүY өсүмдүк (Dzheenbekova, 2017). Кулпунай адамдын организмине керектүҮ түрдүҮ витаминдерге, өзгөчө С витаминге жана фенол кошулмаларына бай келет (Giampieri et al., 2014).

Кулпунай өстүрүүчүлүк Кыргызстанда маанилүү жана артыкчылыктуу багыт болуп саналат. Өлкөдө, 2019жылы кулпунай өстүрүлгөн талаалардын жалпы аянты 430 гектарды түзүп, бул аянттан жалпы 23 миң тонна кулпунай өндүрүлгөн (Anonymous, 2019). Кыргызстанда кулпунай негизинен талаа шарттарында өстүрүлөт, ошондуктан жай мезгилинде бышат жана сатыкка чыгат. Акыркы жылдары кээ бир аймактарда күнөсканалар курулуп, кыш мезгилинде да кулпунайды өстүрүү калыптанууда.

Кулпунай башка өсүмдүктөр сыяктуу эле өстүрүү учурунда түрдүү илдеттер жана зыянкечтер тарабынан жабыркайт. Кулпунайдын негизги илдеттери болуп: боз чирик (Botrytis cinerea); антракноз (Colletottichum fragariae); ак кебер (Sphaerotheca macularis) жана соолуу (Verticillium dahliae) илдеттери катталган (Рaulus, 1990). Ал эми кулпунайды жабыркаткан негизги зыянкечтерге кулпунай канталасы (Lygus rugulipennis); кулпунай узун тумшугу (Anthonomus rubi); желе кенелери (Tetranychus urticae, Phytonemus pallidus); биттер (Myzus persicae); трипстер (Frankliniella occidentalis) жана ак канаттар (Trialeurodes vaporariorum) киришет (Solomon et al., 2001). Илдеттер жана зыянкечтерден сырткары кулпунай өстүрүүдө кээ бир нематоддор да зыян келтире алышат. Бул нематоддор өсүмдүктүн тамыр айланасында жашап, өсүмдүктүн азыктануусун начарлатып, түшүмдү азайтат (LaMondia, 2002).

Кулпунай өстүрүүчүлүктө өсүмдүк паразиттик нематоддору түшүмдү өтө азайтууга жөндөмдүү организмдер (Samaliev and Mohamedova, 2011; Noling, 2016). Мисалы, Египетте жасалган бир излдөөдө кулпунай өстүрүлгөн талааларда 10 уруудагы нематоддор (Meloidogyne, Aphelenchus, Hoplolaimus, Ditylenchus, Tylenchus, Tylenchorhynchus, Trichodorus, Pratylenchus, Aphelenchoides, Xiphinema) бар экендиги аныкталып, алар түшүмдүн 12\% га азаюусун шарттаган (Abd-Elgawad, 2014). Кулпунай үчүн Aphelenchoides fragariae, Aphelenchoides ritzemabosi, Aphelenchoides besseyi жана Ditylenchus dipsaci нематоддору маанилүү экендиги АКШ, Европа, Австралия жана СНГ мамлекеттеринде катталган (Brown et al., 1993; Talavera et al., 2019). Өсүмдүк паразиттик нематоддору түздөн-түз зыянынан сырткары, вирустарды ташуу аркылуу кыйыр түрдө да зыян алып келет. Ошондуктан өсүмдүк өстүрүлгөн талаалардагы паразиттик нематоддорду аныктоо жана алар менен күрөшүү иш-чараларын иштеп чыгуу маанилүү болуп эсептелет.

Өсүмдүк паразиттик нематоддор айыл-чарба өсүмдүктөрүнүн түшүмүнө түздөн-түз таасир көрсөтүп, адамзатка экономикалык жактын чоң зыян алып келет. Кулпунай өстүрүүчүлүктө нематоддор карантиндик коркунучту да жаратып келет. Ошондуктан Кыргызстандын Чүй өрөөнүндө кулпунай өстүрүлгөн талааларда өсүмдүк паразиттик нематоддорду аныктоо актуалдуу тема болуп эсептелет жана бул теманы изилдөөнүн теоретикалык эле эмес, практикалык дагы мааниси бар. Бул изилдөөдө Кыргызстандын Чүй өрөөнүндөгү кулпунай өстүрүлгөн талаалардагы өсүмдүк паразиттик нематоддорду аныктоо максат кылынган.

\section{МАТЕРИАЛДАР ЖАНА МЕТОДДОР}

Кулпунай талааларындагы нематоддорду аныктоо максатында Кыргызстандагы эң көп кулпунай өстүрүлгөн аймактар болгон Чүй облусунун Чүй районундагы (Токмок шаары жана чектешкен айылдар); Аламүдүн районундагы (Көк-Жар, Туңгуч) жана Сокулук районундагы (Кызыл-Туу, Питомник) кулпунай өстүрүлгөн талаалардан жалпы 25 топурак үлгүлөрү чогултулду. Топурак үлгүлөрү алынган талааларга тиешелүY маалыматтар 1-таблицада көрсөтүлгөн. Чүй облусу континенталдык климатка ээ, жайкысын кургак жана ысык болсо, кышкысын суук болот. Жылдык орточо температура 5-8 ${ }^{\circ}$, ал эми жаан-чачын 270-400 мм ди түзөт. Топурактары негизинен ачык-каштан тибиндеги топурактар болуп саналат.

\section{Үлгүлөрдү чогултуу}

Топурак үлгүлөрү. Талаалардан топурак үлгүлөрүн чогултуу үчүн 5 литрлик чака жана кичинекей күрөк колдонулду. Мында, ар бир талаанын четинен 10 метрдей калтырып, андан ары талааны бойлой диагоналдык багытта 10 жерден 100-200 грамм топурак күрөктүн жардамы менен чакага салынды. Топурактар мүмкүн болушунча кулпунайдын тамырына жакын жерде жана отоо чөп жок жерден алынды. Чакадагы топурак 
жакшылап аралаштырылгандан кийин, атайын баштыктарга салынып, этикеткасы жазылгандан кийин лабораторияга алынып келинди. Топурак үлгүлөрү лабораторияда караңгы жерде сакталды.

Өсүмдүк үлгүлөрY. Топурак үлгүлөрүн алуу учурунда талааларда нематоддон жабыркаган симптомдорго окшош күмөндүү өсүмдүктөр визуалдык түрдө текшерилип, эгерде мындай өсүмдүктөр болсо, алар жалбырактары менен кошо пластикалык кутуларга салынып, лабораторияга алынып келинди.

1-таблица. ЧҮй өрөөнүндөгУ ҮлгУ алынган талаалардын өзгөчөлүктөру

\begin{tabular}{|c|c|c|c|c|c|c|c|}
\hline \multirow{2}{*}{ 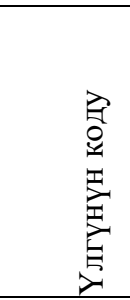 } & \multirow{2}{*}{ 焉 } & \multirow{2}{*}{ 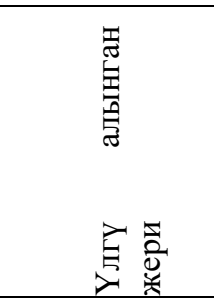 } & \multicolumn{2}{|c|}{ GPS координаттары } & \multirow[b]{2}{*}{ 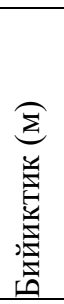 } & \multirow[b]{2}{*}{ 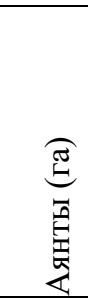 } & \multirow[b]{2}{*}{$\overrightarrow{0}$} \\
\hline & & & $\begin{array}{l}\text { Түндүк } \\
\text { кеңдик (N) }\end{array}$ & $\begin{array}{l}\text { Батыш } \\
\text { узундук (Е) }\end{array}$ & & & \\
\hline КБ-1 & 08.06 .2020 & Көк-Жар & $42^{\circ} 45^{\prime} 23^{\prime \prime}$ & $74^{\circ} 41^{\prime} 35^{\prime}$ & \multirow{6}{*}{$\begin{array}{l}\Sigma \\
\vdots \\
o n \\
\alpha \\
i \\
i n \\
\infty\end{array}$} & 1,5 & Виктория \\
\hline КБ-2 & 08.06 .2020 & Көк-Жар & $42^{\circ} 47^{\prime} 53^{\prime \prime}$ & $74^{\circ} 40^{\prime} 12^{\prime \prime}$ & & 0,5 & Виктория \\
\hline КБ-3 & 08.06.2020 & Көк-Жар & $42^{\circ} 48^{\prime} 04^{\prime \prime}$ & 74³9’36’’ & & 0,5 & Виктория \\
\hline КБ-4 & 10.06 .2020 & Туңгуч & $42^{\circ} 51^{\prime} 47^{\prime \prime}$ & 7441’31'’ & & 0,3 & Виктория \\
\hline КБ-5 & 10.06 .2020 & Туңгуч & $42^{\circ} 50^{\prime} 24^{\prime \prime}$ & $74^{\circ} 41^{\prime} 26^{\prime \prime}$ & & 0,3 & Черный принц \\
\hline КБ-6 & 10.06 .2020 & Туңгуч & $42^{\circ} 50^{\prime} 10^{\prime}$ & $74^{\circ} 41^{\prime} 23^{\prime}$ & & 0,5 & Виктория \\
\hline КБ-7 & 12.06 .2020 & Кызыл-Туу & $42^{\circ} 48^{\prime} 47^{\prime \prime}$ & $74^{\circ} 23^{\prime} 02^{\prime \prime}$ & \multirow{9}{*}{ 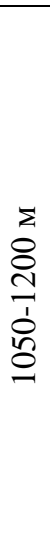 } & 0,3 & Долгоиграющий \\
\hline КБ-8 & 12.06 .2020 & Кызыл-Туу & $42^{\circ} 48^{\prime} 30^{\prime}$ & $74^{\circ} 23^{\prime} 37^{\prime}$ & & 0,5 & Долгоиграющий \\
\hline КБ-9 & 12.06 .2020 & Кызыл-Туу & $42^{\circ} 48^{\prime} 31^{\prime \prime}$ & $74^{\circ} 23^{\prime} 53^{\prime \prime}$ & & 1 & Долгоиграющий \\
\hline КБ-10 & 12.06 .2020 & Кызыл-Туу & $42^{\circ} 48^{\prime} 52^{\prime}$ & $74^{\circ} 23^{\prime} 56^{\prime}$ & & 0,5 & - \\
\hline КБ-11 & 12.06 .2020 & Питомник & $42^{\circ} 48^{\prime} 06^{\prime \prime}$ & $74^{\circ} 21^{\prime} 09^{\prime \prime}$ & & 1 & Долгоиграющий \\
\hline КБ-12 & 12.06 .2020 & Питомник & $42^{\circ} 48^{\prime} 17^{\prime}$ & $74^{\circ} 21^{\prime} 08^{\prime \prime}$ & & 0,4 & Долгоиграющий \\
\hline КБ-13 & 12.06 .2020 & Питомник & $42^{\circ} 47^{\prime} 57^{\prime \prime}$ & $74^{\circ} 20^{\prime} 29^{\prime}$, & & 1 & Долгоиграющий \\
\hline КБ-14 & 12.06 .2020 & Питомник & $42^{\circ} 47^{\prime} 25^{\prime}$ & $74^{\circ} 20^{\prime} 39^{\prime}$, & & 1 & Долгоиграющий \\
\hline КБ-15 & 12.06 .2020 & Питомник & $42^{\circ} 48^{\prime} 01^{\prime \prime}$ & $74^{\circ} 21^{\prime} 20^{\prime \prime}$ & & 0,2 & Долгоиграющий \\
\hline KT-1 & 10.06 .2020 & Токмок & $42^{\circ} 45^{\prime} 06^{\prime \prime}$ & $75^{\circ} 18^{\prime} 04^{\prime \prime}$ & \multirow{10}{*}{$\begin{array}{l}\Sigma \\
0 \\
o n \\
\\
i \\
\infty \\
\infty\end{array}$} & 2,5 & Черный принц \\
\hline KT-2 & 10.06 .2020 & Токмок & $42^{\circ} 44^{\prime} 49^{\prime \prime}$ & $75^{\circ} 17^{\prime} 01^{\prime \prime}$ & & 1 & Черный принц \\
\hline KT-3 & 10.06 .2020 & Бурана жолу & $42^{\circ} 45^{\prime} 45^{\prime}$ & $75^{\circ} 16^{\prime} 28^{\prime}$ & & 3 & - \\
\hline КТ-4 & 10.06 .2020 & Бурана жолу & $42^{\circ} 46^{\prime} 14^{\prime \prime}$ & $75^{\circ} 16^{\prime} 31^{\prime \prime}$ & & 2 & - \\
\hline КТ-5 & 10.06 .2020 & Мээнеткеч & $42^{\circ} 46^{\prime} 30^{\prime \prime}$ & $75^{\circ} 16^{\prime} 53^{\prime \prime}$ & & 0,5 & Черный принц \\
\hline КТ-6 & 10.06 .2020 & Мээнеткеч & $42^{\circ} 46^{\prime} 34^{\prime \prime}$ & $75^{\circ} 17^{\prime} 27^{\prime \prime}$ & & 2 & Виктория \\
\hline КТ-7 & 10.06 .2020 & Мээнеткеч & $42^{\circ} 46^{\prime} 27^{\prime}$ & $75^{\circ} 17^{\prime} 46^{\prime \prime}$ & & 1 & - \\
\hline КТ-8 & 10.06 .2020 & Мээнеткеч & $42^{\circ} 46^{\prime} 09^{\prime}$ & $75^{\circ} 17^{\prime} 51^{\prime \prime}$ & & 0,5 & Черный принц \\
\hline КТ-9 & 10.06 .2020 & Алга & $42^{\circ} 45^{\prime} 20^{\prime \prime}$ & $75^{\circ} 18^{\prime} 29^{\prime}$ & & 2 & - \\
\hline KT-10 & 10.06 .2020 & Алга & $42^{\circ} 45^{\prime} 27^{\prime \prime}$ & $75^{\circ} 18^{\prime} 06^{\prime \prime}$ & & 2,5 & Виктория \\
\hline
\end{tabular}

\section{Нематоддорду топурактан бөлүп алуу}


Лабораториялык иштер Кыргыз-Түрк Манас Университетинин Айыл-чарба факультетиндеги Нематология лабораториясында жүргүзүлдү. Нематоддорду топурактан бөлүп алууда, ар бир үлгүдөн 100 грамм топурак изилдөөгө алынып, Берман чөйчөкчөсү ыкмасынын бираз өзгөртүлгөн абалы Петри - чөйчөкчөсү ыкмасы колдонулду. Бул ыкманын артыкчылыгы болуп, топурактагы активдүү формадагы нематоддор өздөрүнүн аракети менен топурактан сууга өтүүсү камсыз кылынат. Мында, 15 см Петри-чөйчөкчөсүнүн ичине 5 мм бийик болгон электер орнотулуп, электин ичине фильтр кагазы жайгаштырылат. Кагаздын үстүнө топурак салынып, Петри-чөйчөкчөсү менен электин ортосундагы ачык жерден акырындык менен топуракты көмгөндөй кылып суу куюлат. Андан ары нематоддордун сууга өтүүсү үчүн 48 саат бөлмө температурасында күтүлөт. Петри-чөйчөкчөнүн түбүнө чогулган нематоддор 100 мл болгон өлчөөчү цилиндрге куюлуп алынып, 6-8 саат суудагы нематоддордун төмөн көздөй чөгүүсү күтүлөт. Андан ары бул цилиндрлердеги сууну 15 мл калгандай кылып, үстүңкү бөлүгү акырындык менен пипетканын жардамында сордурулат. Калган 15 мл суу атайын тюбиктерге алынып, андар ары ушул суспензия нематоддорду аныктоодо колдонулат. Бул суспензияны көпкө чейин муздаткычта сактоого болот.

\section{Нематоддорду эсептөө жана түрлөрүн аныктоо}

Тюбиктерде сакталган нематоддорду эсептөөдөн мурда, тюбиктин ичинде 1 мл суу калганча үстүңкү бөлүгү пипетканын жардамы менен сордурулуп алынат. Суунун калган бөлүгү микропипетканын жардамы менен жакшылап аралаштырылып, андан 100 мкл өлчөмүндөгү суспензия предметтик айнектин үстүнө тамчылатылат жана үстү жабуучу айнек менен жабылат. Андан ары жарык микроскоптун астында 10-х обьективке коюлуп (100 эсе чоңойтулган болуп саналат), эсептөө жүргүзүлөт. Изилдөө учурунда нематоддорду аныктоо уруулук деңгээлге чейин гана жүргүзүлдү. Нематоддордун уруулары бул макалада авторлордун бири болгон доцент. Докт. Шенол Йылдыз тарабынан аныкталды.

\section{ИЗИЛДӨӨЛӨРДУН ЖЫЙЫНТЫГЫ ЖАНА ТАЛКУУЛОО}

Кыргызстандын Чүй өрөөнүндөгү кулпунай өстүрүлгөн талааларда Tylenchida түркүмүнө таандык Aphelenchoides, Aphelenchus, Criconema, Ditylenchus, Gracilacus, Helicotylenchus, Paratylenchus, Pratylenchus, Tylenchorhynus жана Tylenchus урууларына кирген нематоддор бар экендиги аныкталды (2-таблица).

2-таблица. Чүй өрөөнүндөгү кулпунай талааларындагы өсүмдүк паразиттик нематоддордун уруулары

\begin{tabular}{|c|c|c|c|c|c|c|c|c|c|c|}
\hline & $\begin{array}{c}\frac{a}{d} \\
\frac{a}{2} \\
\frac{0}{0} \\
\frac{0}{0} \\
\frac{1}{2} \\
\frac{1}{1}\end{array}$ & 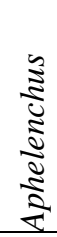 & 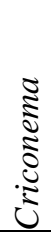 & 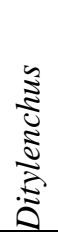 & 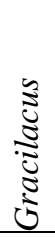 & 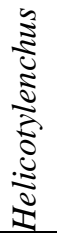 & 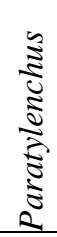 & 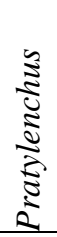 & 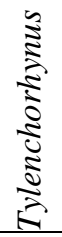 & 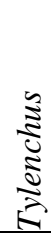 \\
\hline КБ-1 & + & & & & & & & + & + & \\
\hline КБ-2 & & & & + & & & & & + & + \\
\hline КБ-3 & + & & & + & & & & & & \\
\hline КБ-4 & & & & + & & + & & & & \\
\hline КБ-5 & + & + & & + & & + & + & & & + \\
\hline КБ-6 & & & & + & & & & + & & + \\
\hline КБ-7 & + & + & & & & + & & & & + \\
\hline КБ-8 & + & + & & + & & + & + & + & & + \\
\hline КБ-9 & + & + & & + & & + & + & + & + & + \\
\hline КБ-10 & & + & & & & & & & & + \\
\hline КБ-11 & & + & & + & & + & + & + & & + \\
\hline КБ-12 & & + & & & & + & + & + & + & + \\
\hline КБ-13 & & + & & & & + & + & + & + & + \\
\hline КБ-14 & + & + & & + & & + & + & + & & + \\
\hline КБ-15 & & & & + & + & + & + & & & + \\
\hline KT-1 & & & & & & + & & + & & + \\
\hline KT-2 & & & & & & + & & & + & + \\
\hline KT-3 & & & & & & + & & & & + \\
\hline КТ-4 & & & & & & & + & + & & + \\
\hline
\end{tabular}


Esenali uulu et al. / Manas Journal of Agriculture Veterinary and Life Sciences 11 (2) (2021) 179-185

\begin{tabular}{|c|c|c|c|c|c|c|}
\hline KT-5 & & + & & + & & + \\
\hline КТ-6 & + & + & & & & + \\
\hline КТ-7 & & & + & + & & + \\
\hline KT-8 & & + & & & & + \\
\hline КТ-9 & & + & & & + & + \\
\hline KT-10 & & + & & & & + \\
\hline
\end{tabular}

Алынган жыйынтыктарга жараша Tylenchus жана Helicotylenchus уруулары 88 \% жана 72 \% катышы менен эң көп кездешкен уруулар болушту (3-таблица). Бирок, бул эки уруунун тең өкүлдөрү кулпунай үчүн өтө коркунучтуу түрлөрдү камтыбагандыктан, көйгөй катары бааланган жок. Илимий эмгектерде Tylenchus жана Helicotylenchus урууларына кирген нематоддор маданий өсүмдүктөр үсүн экономикалык жактан маанилүү эместиги белгиленген (Thorne, 1962). Ошондой эле биздин жыйынтыктарды Dzhunusov \& Nurgazieva (2016), тарабынан жасалган изилдөөдө Tylenchus уруусу Чүй өрөөнүндөгү түрдүҮ топурактардаа кеңири таралгандыгы жазылган жыйынтыктар да бышыктап турат.

3-таблица. Чүй өрөөнүндөгү кулпунай талааларындагы өсүмдүк паразиттик нематоддордун кездешүүсү жана жыштыльы

\begin{tabular}{lll}
\hline & Кездешүусу (\%) & Жыштыгы* \\
\hline Aphelenchoides & 28 & $32(10-90)$ \\
Aphelenchus & 36 & $105(20-230)$ \\
Criconema & 4 & 10 \\
Ditylenchus & 40 & $55(10-170)$ \\
Gracilacus & 4 & 10 \\
Helicotylenchus & 72 & $37(10-120)$ \\
Paratylenchus & 40 & $41(10-60)$ \\
Pratylenchus & 48 & $19(10-50)$ \\
Tylenchorhynus & 28 & $25(10-90)$ \\
Tylenchus & 88 & $144(20-490)$ \\
\hline
\end{tabular}

*Өсүмдүк нематоддорунун жыштыгы - 25 талаадан алынган үлгүлөрдөн 100 грамм топурактагы жыштыгы өзөзүнчө эсептелип, таблицада орточо тыгыздык (эң төмөнкү жыштык - эң жогорку жыштык) көрсөтүлдү

Биздин изилдөөдө Tylenchus жана Helicotylenchus урууларынан башка уруулардын кездешүүсү 50 \% дан төмөн болушуп, тыгыздыгы жагынан да төмөн көрсөткүчтөргө ээ экендиги байкалды (3-таблица). Кулпунай үчүн маанилүү өсүмдүк-паразиттик нематоддоруна ээлик кылган Aphelenchoides жана Ditylenchus уруулары Чүй облусунун Аламүдүн жана Сокулук райондорунан алынып келинген топурак үлгүлөрүнөн аныкталып, бирок, жыштыгы жагынан төмөн деп бааланды. Aphelenchoides уруусуна кирген Aphelenchoides fragariae нематоду дүйнөдө, өзгөчө, Жер Ортолук деңиз чөлкөмүндөгү өлкөлөрдө кулпунайдын көчөттөрүнүн маанилүү зыянкечи болуп саналат (Özarslandan, 2019). Биз изилдеген топурактардын ичинен 3 гана үлгүдөн (КБ-8, КБ-9 жана КБ14) A. fragariae га жакын нематоддор аныкталды. Бул изилдөөдө, үлгүлөрдүн түрдүк деңгээлде аныкталуусу так жасалбагандыктан, Aphelenchoides уруусу ичинде гана берилди. Ал эми изилдөө учурунда Ditylenchus уруусуна кирген башка маанилүҮ нематод түрү болгон Ditylenchus dipsaci 2 топурак (КБ-12 жана КБ-15) үлгүсүнөн аныкталды. D.dipsaci көптөгөн өлкөлөрдө кулпунайдын зыяндуу нематодасы болуп, ал өсүмдүк вирустарын ташуусу белгиленген (Enneli жана Ozturk, 1989; Park et al., 2005). Бул түр кулпунайдан сырткары беде, кант кызылчасы, пияз, ж.б. көптөгөн өсүмдүктөр үчүн да кооптуу болуп саналат (Karani жана Karegar, 2013).

Илимий эмгектерде кулпунай талааларында тамыр-шишик нематоддорунун (Meloidogyne уруусу) болушу жана маанилүү зыяны тууралуу жазылган (Chen жана Tsay, 2006). Мисалы, Испаниядагы кулпунай өстүрүлгөн талаалардын топурактарында тамыр-шишик нематоддор 90\% кездешип, анын ичинен M. hapla эң көп таралган түр болгон (Talavera et al., 2019). Ал эми, биздин изилдөөнүн алкагында алып келинген топурак үлгүлөрүнөн 
Meloidogyne уруусуна кирген түрлөр табылган жок. Бул да болсо, биздин өлкөбүздүн топурактары таза экендигинен кабар берет.

\section{КОРУТУНДУ}

Бул илимий изилдөөнүн алкагында алынган жыйынтыктарга жараша, Кыргызстандын Чүй өрөөнүндөгү кулпунай өстүрүлгөн талааларында кээ бир өсүмдүк паразиттик нематоддору бар экендиги аныкталып, бирок, бул нематоддордун түрлөрү, кездешүү пайызы жана жыштыгы жагынан азырынча көйгөй эмес экендиги аныкталды. Кулпунайдын коркунучтуу нематодасы, Aphelenchoides fragariae, талааларда өтө аз жыштыкта экендиги белгилүү болду. Үлгүлөрдөн Meloidogyne уруусуна кирген түрлөр табылган жок. Бул да болсо, биздин өлкөбүздүн топурактары таза экендигинен кабар берет. Мындан ары кулпунай талааларындагы нематоддорду изилдөө, алардын экономикалык жактан маанилүүлүктөрүн белгилөө жана топурактагы башка организмдер менен ортосундагы байланыш механизмдерин изилдөө иштери улантылуусу зарыл.

\section{КЫЗЫКЧЫЛЫКТАРДЫН КАГЫЛЫШЫ}

Бул макалада кызыкчылыктардын кагылышы жок.

\section{АВТОРЛОРДУН САЛЫМЫ}

Бул макалада авторлор бирдей өлчөмдө салым кошкон.

\section{КОЛДОНУЛГАН АДАБИЯТТАР}

Anonymous 2019. FAOSTAT. http://www.fao.org/faostat/en/\#data/QC (access date: 20.04.2021)

Dzheenbekova, B. Dzh. 2017. Investigation of grooving agro-technologies of strawberry. Annals of Vuzov Kyrgyzstan, (11), 49-52.

Dzhunusov, K. K., \& Nurgazieva, D. B. Ecological bases of sugar beet nematodes in Chui region. Annals of Vuzov Kyrgyzstan, № 2, 2016

Abd-Elgawad, M. 2014. Yield losses by phytonematodes: challenges and opportunities with special reference to Egypt. Egyptian Journal of Agronematology, 13(1), 75-94.

Brown, D.J.F., Dalmasso, A., \& Trudgill, D.L. 1993. Nematode pests of soft fruits and vines. In Plant Parasitic Nematodes in Temperate Agriculture; Evans, K., Trudgill, D.L., Webster, J.M., Eds.; CAB International: Wallingford, UK

Chandler, C. K., Folta, K., Dale, A., Whitaker, V. M., \& Herrington, M. 2012. Strawberry. In Fruit breeding (pp. 305325). Springer, Boston, MA.

Chen, P., \& Tsay, T. 2006. Effect of crop rotation on Meloidogyne spp. and Pratylenchus spp. populations in strawberry fields in Taiwan. Journal of nematology, 38(3), 339.

Enneli, S. \& Öztürk, G. 1989. Zonguldak ilinin çilek yetiştirilen alanlarinda bulunan bitki paraziti nematodlarin saptanmasi ve önemli olanlarin yoğunluklarinin belirlenmesi üzerinde çalişmalar. Bitki koruma bülteni 1989, 29 (34): $153-163$

Giampieri, F., Alvarez-Suarez, J. M., \& Battino, M. 2014. Strawberry and human health: Effects beyond antioxidant activity. Journal of agricultural and food chemistry, 62(18), 3867-3876.

Karani, S. H. M., \& Karegar, A. 2013. First report of the stem and bulb nematode, Ditylenchus dipsaci, on strawberry in northern Iran. Iranian Journal of Plant Pathology, 49(2).

LaMondia, J. A. 1999. Influence of rotation crops on the strawberry pathogens Pratylenchus penetrans, Meloidogyne hapla, and Rhizoctonia fragariae. Journal of nematology, 31(4S), 650.

Noling, J. W. 2016. Nematode management in strawberries, University of Florida publication Series no. ENY-031, USA, 12 .

Samaliev, H. Y., \& Mohamedova, M. 2011. Plant-parasitic nematodes associated with strawberry (Fragaria ananassa Duch.) Bulgaria. Bulgarian J. of Agricultural Science, 17(6), 730-735.

Solomon, M. G., Jay, C. N., Innocenzi, P. J., Fitzgerald, J. D., Crook, D., Crook, A. M., ... \& Cross, J. V. 2001. Natural enemies and biocontrol of pests of strawberry in northern and central Europe. Biocontrol Science and Technology, 11(2), 165-216. 
Özarslandan, A. 2019. Doğu Akdeniz Bölgesi’nde Sera Alanında Çilek Yaprak Nematodu (Aphelenchoides fragariae)(Nemata: Aphelenchida)'nun Tespiti. Kahramanmaraş Sütçü Imam Üniversitesi Tarım ve Doğa Dergisi, 22(1), 52-56.

Park, S. D., Khan, Z., Yeon, I. K., \& Kim, Y. H. 2005. A survey for plant-parasitic nematodes associated with strawberry (Fragaria ananassa Duch.) crop in Korea. The Plant Pathology Journal, 21(4), 387-390.

Paulus, A. O. 1990. Fungal diseases of strawberry. HortScience, 25(8), 885-889.

Talavera, M., Miranda, L., Gómez-Mora, J. A., Vela, M. D., \& Verdejo-Lucas, S. 2019. Nematode management in the strawberry fields of southern Spain. Agronomy, 9(5), 252.

Thorne, G. (1962). Principles of nematology. Soil Science, 93(1), 70. 